\title{
The Influence of Organizational Commitment and Ethical Leadership Toward Employee Competency of the Department of Education in Tasikmalaya
}

\author{
Maya Puspita Dewi ${ }^{1}$, Muh Barid Nizarudin Wajdi ${ }^{2}$ \\ Institut Ilmu Sosial dan Manajemen Stiami, Indonesia ${ }^{1}$ \\ STAI Miftahul Ula Nganjuk, Indonesia ${ }^{2}$ \\ $\left\{\right.$ maya.pd@stiami.ac.id $\left.{ }^{1}, \underline{\text { baridnizar84@gmail.com }}{ }^{2}\right\}$
}

\begin{abstract}
This study aims to examine and determine the influence of organizational commitment and ethical leadership on the employee competency of the Department of Education Office in Tasikmalaya. This study used a quantitative approach by conducting a field survey. There were 100 employees used as a sample with a simple random sampling technique. The data were analyzed using correlation and regression techniques. The result of this study shows that there is an influence of organizational commitment to the employee competency. There is also an influence of ethical leadership on the employee's skill, as well as the influence of organizational commitment and moral leadership on the employee's competency of the Department of Education Office in Tasikmalaya. The percentage of the importance of organizational commitment and ethical guidance on the skill of Department of Education Office staff in Tasikmalaya is $21.7 \%$ while the remaining $78.3 \%$ is influenced by other variables that were not examined.
\end{abstract}

Keywords: Organizational commitment, Ethical leadership, Employee competency.

\section{Introduction}

Humans play a very important role in the organization. They have a position and role in organizational performance[1]. Faustino Cardoso Gomes[2] suggests that the most factor that influences the performance of each organization is human behavior. Humans are the most important element in the administration and management process for all organizations. Its human behavior determines the effectiveness of organizational management[3][4].

In general, organizations are oriented to several objectives that will lead to organizational decisions and activities. Employees are one of the components that play an important role in determining organizational success. They are required to have good competence to do a job properly. However, in practice, it indicates that there are many employees who do not do their job properly as the expectation of the institution where they work. It happens because of their enthusiasm and competencies are still low.

In the management of educational institutions, if work spirit of the employees is low, it can causes decrease in employee competency which affecting the overall performance of the institution. Regarding the performance of an institution depends on the competency of its 
employees, then for the implementation of the organization's vision and mission, it needs to be supported by the employees who have high organizational commitment. Therefore the employees in doing their job are required to have a sense of responsibility, discipline, seriousness, and sincerity. Moreover, they are also required to work efficiently, effectively and productively, so that they can make a meaningful contribution to improving organizational performance.

To achieve optimal employee competencies, the development that oriented to the vision and mission of the progress of the institution in achieving the stated goals is necessary[4]. Employee development is an important effort in organizing institutions to achieve optimal organizational performance. Therefore, employee development needs to be done in a serious, directed, and planned manner. Besides, effectiveness and efficiency are needed as an effort in helping organizational managers to avoid themselves from obsolescence and to do the job more effectively.

Since the key to successful development depends on its human resources, competencies are becoming national issues because it involves the quality and the development of human resources which are getting the concern in the future. Generally, Government employees in Indonesia are seen incompatible to the demand and needs of the community. For this reason, the development of the potential possessed by employees is needed as an effort to improve employee competency.

Government employees are an important and dominant factor in the process of service to the community[5]. This is because the government employees are the main implementing element of the government bureaucracy which functions as civil servants[6]. Many factors are related and influence on government performance, such as commitment to organization, leadership, compensation, social security, education levels and training, work ethics, motivation, health, human relations, management, production facilities, opportunities for achievement, satisfaction, technology, and government policy"[7][8].

Competence is an individual's capacity to do various tasks in a job[9], [10]. Many factors that affect the competence of government employees such as organizational commitment and ethical leadership are factors that determine employee competency. Local government bureaucratic management can be managed effectively if it supported by strong organizational commitment and effective leadership implementation[11].

In carrying out its main duties and functions, the Department of Education Office in Tasikmalaya is responsible for assisting the regional autonomy implementation in terms of the authority in the education sector which is the duty of the Local Government of Tasikmalaya. To support and assist the Local Government of Tasikmalaya in implementing its function, the Department of Education establishes the vision of "Creating Human Resource with Intelligent, Character,and Moral." The vision is implemented through a mission by focusing on enhancing education expansion and equity, improving education quality and relevance, developing education systems and management and empowering educational institutions towards independence. However in implementing its mission, Department of Education in Tasikmalaya having several problems especially related to the low competence of their staff, lack of basic education facilities and infrastructure, community participation in education is not optimal, leadership style that oriented to the political interests which ignore education processes and outputs, and lack of organizational commitment in the Department of Education in Tasikmalaya.

Based on the facts described above, the problem examined in this paper is whether there is an influence of organizational commitment and ethical leadership on the competence of employee in the Department of Education in Tasikmalaya 


\section{Method}

This research approach was quantitative by using the survey method which is conducting research directly into the field. The questionnairewas used as a data collection tool. The data was collected by using questionnaires that developed by researchers, and it was given to the samples from the population of this study. The population of this study was all employees of the Department of Education Office in Tasikmalaya with the 100 employees as a sample. The sample was determined by using simple random sampling technique. The instrument of organizational commitment, ethical leadership,and teacher competency was validated with the product moment correlation formula, while reliability was measured by the Alpha Cronbach formula. Meanwhile, data analysis using correlation techniques and multiple linear regression.

\section{Result and discussion}

The influence of organizational commitment and ethical leadership on the employee competency of the Department of Education in Tasikmalaya was shown by the linear regression equation $\hat{\mathrm{Y}}=78.838+0.291 \mathrm{X} 1+0.99 \mathrm{X} 2$. The regression equation showed the meaning at the 0.05 level of significance. From the regression model, it can be interpreted that changes in one unit score of organizational commitment and ethical leadership will be followed by changes in employee competency scores of 0.291 units of organizational commitment and 0.99 of ethical leadership in the same direction as the constant (intercept) of 78.838. Thus, it can be predicted the increasing score of organizational commitment and ethical leadership to the increasing of the employee competency of Department Education in Tasikmalaya as seen in the following table:

Table 1. Coefficients

\begin{tabular}{cccccc}
\hline \multirow{2}{*}{ Model } & \multicolumn{2}{c}{ Unstandardized Coefficients } & StandardizedCoefficients & T & Sig. \\
& $\mathrm{B}$ & Std. Error & Beta & & \\
\hline (Constant) & 78.838 & 80.383 & & .981 & 000 \\
X1 & .291 & .676 & .075 & .431 & .669 \\
X2 & .099 & .337 & .051 & .294 & .770 \\
\hline
\end{tabular}

a. Dependent Variable: Y

There is an influence of organizational commitment on the employee competency of the Department of Education in Tasikmalaya. Based on the F test, obtained Fcount of 40.270 at a significance level of 0.003 . Because the probability $(0.003)$ is much smaller than 0.05 , the regression model can be used to predict the employee competency of the Department of Education in Tasikmalaya. Because the probability in the $\mathrm{F}$ test is 0.003 is much smaller than 0.05 , then the regression model is significant, this means that the organizational commitment influences the employee competency of the Department of Education in Tasikmalaya. 
Table 2. ANOVA ${ }^{\mathrm{a}}$

\begin{tabular}{cccccc}
\hline Model & Sum of Squares & Df & Mean Square & F & Sig. \\
\hline Regression & 25.555 & 1 & 25.555 & 40,270 & $.003^{b}$ \\
Residual & 2894.220 & 38 & 76.164 & & \\
Total & 2919.775 & 39 & & & \\
\hline
\end{tabular}

a. Dependent Variable: Y

b. Predictors: (Constant), X1

From the calculation of the coefficient of determination in the following table, $\mathrm{X} 1$ and $\mathrm{X} 2$ obtained the price of $\mathrm{r} 2=0.217$. It means that the employee competency of the Department of Education in Tasikmalaya can be explained by the organizational commitment and ethical leadership of $21.7 \%$. In other words, the influence percentage of organizational commitment and ethical leadership on the employee competency of the Department of Education in Tasikmalaya is $21.7 \%$. The remaining $78.3 \%$ is influenced by other variables that were not examined.

Table 3. Model Summary

\begin{tabular}{ccccc}
\hline Model & $\mathrm{R}$ & R Square & $\begin{array}{c}\text { Adjusted R } \\
\text { Square }\end{array}$ & $\begin{array}{c}\text { Std. The error of } \\
\text { the Estimate }\end{array}$ \\
\hline 1 & $.540^{\mathrm{a}}$ & .291 & .217 & 8.727 \\
\hline
\end{tabular}

a. Predictors: (Constant), X1

The results of this study indicate that, if organizational commitment tends to be good and ethical leadership tends to be effective, then the employee competency of the Department of Education in Tasikmalaya tends to increase.

\subsection{Employee Competence}

In every organization, competence is an important aspect to achieve goals. Achieving goals is the result of good individual and group performance. On the Contrary, failure to achieve the goals that have been formulated is also a result of the performance of individuals and groups that are not optimal.

Robin stated that competence is an individual's capacity to do various tasks in a job[9], [10]. According to Dinglecompetence is the ability of an employee to achieve a certain performance from a job that is his / her responsibility, which is fulfilled by the effective and efficient elements[12]. A similar opinion is expressed by Gilmore and Carson that competence is the ability to use knowledge and skills effectively in achieving performance[13].

According to Miyawaki in Mohd Noor \& Dola [14][15], competence is a talent needed to improve basic skills to improve high performance. Related to Spencer and Spencer (1993: 9) stated that, competence is the basis of individuals who are associated with effective and superior performance at work.

An employee who has high competencies such as knowledge, skills, abilities, and attitudes that appropriate to the position they assigned is always motivated to work effectively, efficiently and productively. It happens because the competencies possessed by the employee are increasingly able to carry out the tasks that are charged to him. Human resources have an important role in achieving organizational goals because the success of an organization is influenced by the resources within the organization, both human and financial resources. 
Based on the description above, it can be stated that competence is the ability of employees to integrate the mastery of knowledge, skills, values, and attitudes reflected in the thinking and acting behavior in carrying out their work that fit their profession.

\subsection{Organizational Commitment}

Organizational commitment is a strong desire to remain as a member of a particular organization. It is a desire to strive according to the wishes of the organization, as well as certain beliefs and acceptance of the values and goals of the organization. In other words, it is an attitude that reflects employee loyalty to the organization and an ongoing process where organizational members express their concern for the organization and success and continuous progress[16].

According to Robbins [17], there are three types of organizational commitment, including Affective Commitments, Normative Commitments, and Sustainable Commitments. Affective Commitment is an emotional feeling for the organization and confidence in its values. Normative commitment is the feeling of being obliged to remain in the organization because it must be so, and this action is the right thing to do. Sustainable commitment is the economic value that represents a sense to remain in an organization when compared to leaving the organization.

Organizational Commitment is defined as "The degree to which an employee identifies with a particular organization and its goals, and wishes to maintain membership in the organization"[18]. According toPorter et all[19]Organizational commitment is the relative strength of the individual and their involvement in a particular organization, indicating by three psychological factors: (1) strong motivation to remain a member of the organization, (2) a strong desire to strive for organizational progress and (3) a sense of acceptance of organizational values and goals.

Regarding the form of organizational commitment, Allen and Meyer [20] divided into three forms : (1) affective commitment that represents emotional attachment, the desire of individuals to be involved in the organization without any influence from others. (2) Continuous commitment is individual considerations to remain involved in the organization due to the fulfillment of needs, and (3) Normative Commitments is individual beliefs about staying loyal to the organization. The three approaches stated that organizational commitment is an employee psychological condition that related to the organization whether they remain or leave the organization. The result of the study on Salim, S. Sadruddin and D. Zakus[21] concluded that employee commitment is generally based on their perceptions of their employer's support and the actions of certain organizations in the hope that their organization is fair to employees, the compensation provided meet their needs and the work environment is profitable.

\subsection{Ethical Leadership}

Ethical leadership is defined by Brown as "the demonstration of normatively appropriate conduct through personal actions and interpersonal relationships and the promotion of such conduct to followers through two-way communication, reinforcement and decision making"[22]. The definition contains three elements: (1) accentuating the right action normatively through the behavior, (2) accentuating the right action normatively through interpersonal action; and (3) the promotion of right action to experts addresses two mediums of communication, reinforcement and decision making. 
According to Trevino, ethical leadership was built on two main factors. These factors consist of the position of a leader as a moral person and the position as a moral manager[23]. Both of these show a summary of the ethical leadership factors described by Trevino [22]

According to Trevino, the principle of ethical leadership requires a leader who have an ethic. In the context of gaining a reputation, a leader needs to emphasize himself in real terms as an ethical individual. Therefore, the leader needs to emphasize the ethical elements of his nature, behavior and decision making. The second is carrying out the task of managing ethics and making ethics the main agenda of leadership. In the context of ethics manager, a leader needs to carry out a role as a practice model in the organization, giving rewards and penalties, and communicating ethics and values to all organizational experts through certain programs. Also, according to Zhu, the element of authenticity is necessary since ethical leadership can give an impression to workers' behavior. Authenticity is needed for every leader to ensure the harmony between his ethical intentions and his actions is in the right path.[22].

Ethical leaders think of the long-term consequences, disadvantages, and benefits of the decisions they make in the organization. They are humble, care, strive for justice, take responsibility and show respect for each. Ethical leaders set high ethical standards and act according to them. They influence the values of organizational ethics through their behavior. Leaders function as role models for their followers and show them the limits of behavior that are regulated in an organization. They are regarded as honest, trustworthy, courageous and showing integrity. More leaders are "walking in the conversation," translating values internalized into action, the higher levels of trust and respect that they generate from followers.

Based on this description, it can be stated that ethical leadership can be measured from (1) representing as someone who has ethical qualities, (2) implementing ethical behavior in leadership interaction activities; and (3) the promotion of ethical action by referring to the rules and through the two-way communication medium, reinforcement and decision making.

\section{Conclusion}

Based on the results of the study, it can be concluded that the influence of organizational commitment and ethical leadership on the employee competency of the Department of Education in Tasikmalaya, both individually and group as follows:

There is an influence of organizational commitment on the employee competency of the Department of Education in Tasikmalaya

There is an influence both from organizational commitment and ethical leadership on the employee competency of Department of Education in Tasikmalaya with a relationship strength of R2 $=21.7 \%$ at the confidence level $\alpha=0.05$, and the form of the relationship is expressed in the multiple linear regression equation $\hat{Y}=78.838+0.291 \mathrm{X} 1+0.99 \mathrm{X} 2$.

The Determination Coefficient shows $21.7 \%$ employee competency can be explained by organizational commitment and ethical leadership or the influence percentage of organizational commitment and ethical leadership on the employee competency of Department of Education in Tasikmalaya is $21.7 \%$, and the remaining $78.3 \%$ is influenced by other variables not examined.

Based on the conclusions described above, this study has successfully tested the hypothesis that organizational commitment and ethical leadership, both individually and group influence the employee competency of the Department of Education in Tasikmalaya. Therefore, in an effort to improve the competency of Tasikmalaya Department of Education Office staff, it is necessary to make various strategic breakthroughs that can increase employee commitment to the institution by providing compensation in accordance with the level of employee life needs, 
giving performance achievements to employees who have achievements, as well as various activities development that can support the existence of high employee loyalty to institutions, leadership policies that are oriented towards increasing employees to be able to think creatively, innovatively, and transformatively in achieving organizational goals.

\section{References}

[1] A. Ikhwan, "Model Organisasi Ideal Bagi Perguruan Tinggi Islam di Indonesia," Ta'allum J. Pendidik. Islam, vol. 1, no. 1, pp. 29-36, 2013.

[2] G. Faustino Cardoso, Manajemen Sumber Daya Manusia. Jakarta: Bina Aksara, 2001.

[3] A. Ikhwan, "MANAGEMENT OF LEARNING ASSESSMENT USING CURRICULUM 2013 (CASE STUDY IN ISLAMIC PRIMARY SCHOOL (MI) MUHAMMADIYAH 5 WONOASRI PONOROGO - EAST JAVA - INDONESIA)," MUADDIB Stud. Kependidikan dan Keislam., vol. 08, no. 02, pp. 108-123, 2018.

[4] A. Ikhwan, "Development Of Quality Management Islamic Education In Islamic Boarding School (Case Study Madrasah Aliyah Ash Sholihin)," Al-Hayat J. Islam. Educ., vol. 1, no. 1, p. 117, 2017.

[5] U. Sidiq and A. Ikhwan, "Local Government Policy Regarding Mandatory Students Diniyah Takmiliyah in Indramayu Regency," KARSA J. Soc. Islam. Cult., Jul. 2018.

[6] A. Ikhwan, "Penerapan Manajemen Hubungan Sekolah dan Masyarakat dalam Perspektif Islam," Al-Hayat J. Islam. Educ., vol. 2, no. 1, p. 1, 2018.

[7] A. Ikhwan, "Leadership in Islamic Education; Study of Thematic Al-Qur'an and AlHadist," Ulul Albab J. Stud. Islam, vol. 17, no. 1, p. 3, 2016.

[8] A. Ikhwan, "Sistem Kepemimpinan Islami Instrumen Inti Pengambil Keputusan pada Lembaga Pendidikan Islam," Istawa J. Pendidik. Islam, vol. 3, no. 2, pp. 111-154, 2018.

[9] S. P. Robbins and T. A. Judge, "Perilaku organisasi (Organizational behavior)," Jakarta: Salemba Empat, 2008.

[10] S. P. Robbins and T. A. Judge, Organizational behavior. New Jersey: Prentice Hall, 2008.

[11] B. N. Wajdi, “The Differences Between Management And Leadership," Sinergi J. Ilm. Ilmu Manaj., vol. 7, no. 1, Jul. 2017.

[12] J. Dingle, "Analysing the competence requirements of managers," Manag. Dev. Rev., vol. 8, no. 2, pp. 30-36, 1995.

[13] M. O'Dwyer, A. Gilmore, and D. Carson, "Strategic alliances as an element of innovative marketing in SMEs,” J. Strateg. Mark., vol. 19, no. 01, pp. 91-104, 2011.

[14] K. B. M. Noor and K. Dola, "Job competencies for malaysian managers in higher education institution," Asian J. Manag. Humanit. Sci., vol. 4, no. 4, pp. 226-240, 2009.

[15] A. F. Rodli, A. Prasnowo, M. B. N. Wajdi, and S. Sajiyo, "Building a Culture of Learning to Accelerate the Advancement of Higher Learning," in International Conference on Religion and Public Civilization (ICRPC 2018), 2018.

[16] F. Luthan, Organization Behavior (Prilaku Organisasi). Yogyakarta: Andi, 2006.

[17] S. P. Robbins, Organizational behavior: Concepts, controversies, and applications. New Jersey: Prentice Hall, 1991.

[18] S. P. Robbins, "Organizacinès elgsenos pagrindai," Kaunas Poligr. ir Inform., vol. 324, 2003.

[19] L. W. Porter and R. M. Steers, "Organizational, work, and personal factors in employee turnover and absenteeism.," Psychol. Bull., vol. 80, no. 2, p. 151, 1973. 
[20] J. P. Meyer and N. J. Allen, "A three-component conceptualization of organizational commitment," Hum. Resour. Manag. Rev., vol. 1, no. 1, pp. 61-89, 1991.

[21] L. Salim, S. Sadruddin, and D. Zakus, "Organizational commitment in a Health NGO in Pakistan," Volunt. Int. J. Volunt. Nonprofit Organ., vol. 23, no. 3, pp. 584-604, 2012.

[22] M. E. Brown, L. K. Treviño, and D. A. Harrison, "Ethical leadership: A social learning perspective for construct development and testing," Organ. Behav. Hum. Decis. Process., vol. 97, no. 2, pp. 117-134, 2005.

[23] C. C. Theron and H. H. Spangenberg, "Confirmatory factor analysis of the performance management audit questionnaire," South African J. Psychol., vol. 30, no. 4, pp. 32-39, 2000. 